$$
\text { DOE/ER/45541-TI }
$$

\title{
ANNUAL REPORT AND EXTENSION PROPOSAL
}

to the

\section{Department of Energy}

Grant No. DE-FG03-95-ER45541 A001

by C. A. Angell

Department of Chemistry

Arizona State University

Tempe, AZ 85287-1604

(602) $965-7217$

(602) $965-7972$ (Fax)

caa@asu.edu

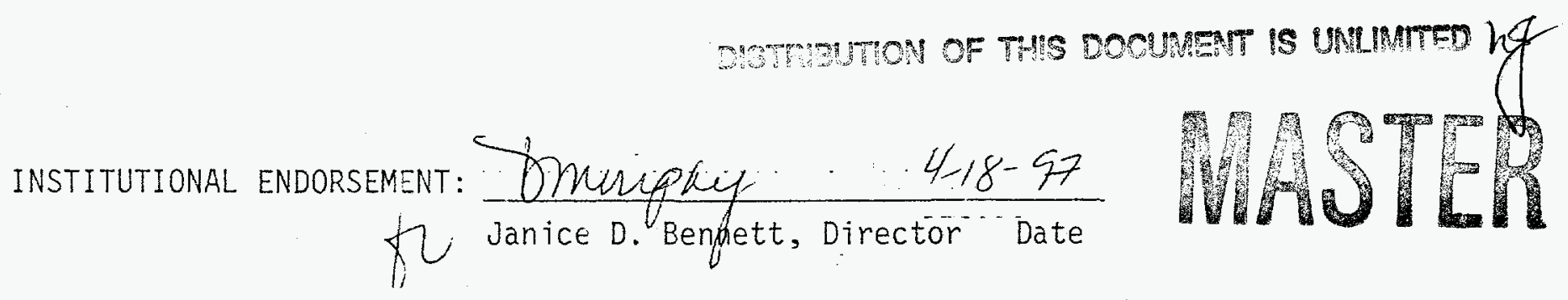

DISCLAIMER

This report was prepared as an account of work sponsored by an agency of the United States Government. Neither the United States Government nor any agency thereof, nor any of their employees, makes any warranty, express or implied, or assumes any legal liability or responsibility for the accuracy, completeness, or usefulness of any information, apparatus, product, or process disclosed, or represents that its use would not infringe privately owned rights. Reference herein to any specific commercial product, process, or service by trade name, trademark, manufacturer, or otherwise does not necessarily constitute or imply its endorsement, recommendation, or favoring by the United States Government or any agency thereof. The views and opinions of authors expressed herein do not necessarily state or reflect those of the United States Government or any agency thereof. 


\section{DESCLAMER}

Portions of this docoment may be illegibie in electronic inage produets. Imsges are produced from the best available original document 


\section{A. BACKGROUND}

The research proposed for the current grant consisted of five components, of which we have made substantial progress on three and have performed some exploratory work on a sixth for which we present here an argument for extending.

The components on which we have made progress are:

(1) "Development of and improvement on the basic polymerin-salt idea. This will be separated into parts dealing with

(i) improvements in salt constitution, and

(ii) improvements in polymer type, emphasizing the role of anionic polymers;"

(2) "Modifications of the polymer-in-salt electrolyte to include the addition of solid particulates to the saltpolymer matrix;" and

(5) "Physical measurements."

The new componen: on which we have made some preliminary measurements over the summer period (by a student previously supported on teaching assistantship), concerns the use of electrolytes developed under the present and other programs for improving the performance of photovoltaic cells. The rationale is that hole/electron separation in semiconductors under irradiation is aided by trapping the holes on a redox species in an adjacent electrolyte solution. The efficiency is proportional to a number of factors not fully understood, one of which is determined by the character of the electrolyte. Sin "e we have new types of electrolytes under development, and since solar energy via photovoltaics is an envircmentally important aspect of the energy sciences, we felt it was a desirable aspect of materiais science to study in a laboratory in Arizona. We would now like to propose it for continuation under the present program.

\section{B. ACHIEVEMENTS IN THE PAST YEAR}

1. New low-melting lithium salts and solutions (work of C. Liu)

New low-melting iithium salis and solutions have been discovered by using the Lewis acid $\mathrm{AlCl}_{3}$ to complex the basic anions of salts like LiSCN and LiCNO.

It has been mote than thirty years since the system $\mathrm{AlCl}_{3}+$ $\mathrm{LiCl}$, in which the tetrahedral anion $\mathrm{AlCl}_{4}^{-}$forms by an acid-base reaction, was invesiigated. It was found then that the products of 
this reaction melted at much lower temperatures than the $\mathrm{LiCl}$, indeed the lithium tetrachloraluminate is one of the lowest-melting lithium salts known and one of the best conducting also. The salt LiSCN is much lower melting than $\mathrm{LiCl}$, and we have found thit by careful combination in the absence of moisture we can obtain compounds $\mathrm{LiAlCl}_{3} \mathrm{SCN}$ (and also $\mathrm{LiAlCl}_{3} \mathrm{CNO}$ ) which are even lower melting than $\mathrm{LiAlCl}_{4}$. Indeed they are so low-melting that they are extremely slow to crystallize hence provide us with the first easily glassforming lithium "tetra-haloaluminate" salts ever described (Here we have adopted the common description of $\mathrm{SCN}^{-}$as a pseudo halide). We will describe below a very recent development in which a true tetrahaloaluminate glassformer has been found.

A phase diagram and various physical measurements have been obtained on the $\mathrm{LiSCN}+\mathrm{AlCl}_{3}$ system, and on the $\mathrm{Na}$ and $\mathrm{K}$ equivalents as well, and have been described in the first paper listed in the "Publications" section below. The conductivity at ambient temperature is very high, though unfortunately not as high as expected from extrapolations from the melt of $\mathrm{LiAlCl}_{4}$ itself. This is consequence of the SCN-based liquid having a higher glass transition temperature.

The latter is itself probably a consequence of the extra steric hindrance to rotation of the tetraXaluminate anions due to the protruding $\mathrm{SCN}^{-}$wich can also serve as a transient bridging species. This suggested that the best performance would be obtained with an all-halide melt. Since some of the applications for electrolytes, such as the Li/sulfur cell being developed by Moltech Corp., which has licensed our technology, do not require a very high voltage window, it seemed worthwhile to investigate the glassforming behavior of mixed chloride iodide haloaluminates

$\mathrm{LiAlCl}_{4}$ and $\mathrm{LiAll}_{4}$ solutions were prepared and the temperature of the eutectic was identified at $70^{\circ} \mathrm{C}$, lower than in any of the other aluminate systems measured to date. It was found that a range of solutions around the eutectic composition was indeed glassforming, and the glass transition temperatures were as low as extrapolated for the tetrachloraluminate itself, viz. $-40^{\circ} \mathrm{C}$. The conductivity was found to be correspondingly high near $\mathrm{T}_{\mathrm{g}}$ and above the melting point, but unfortunately the supercooled liquid was not stable against crystalization at room temperature. It may be that small additions of third components will stabilize the melt kinetically or thermodynamically and that a superior electrolyte will be the result. 


\section{Other electrolytes. (Work of M. Videa)}

A study has been completed of the properties of the $\mathrm{AlCl}_{3}$ based systems in which the salt carrying the basic anion is $\mathrm{Li}$ methanesulfonimide ( $\mathrm{Li}$ "imide") This complex seems never to crystallize, but unfortunately is not a good ionic conductor by itself. Its properties in binary mixtures, however, perform better, and a manuscript describing the glassforming range and conductivity in the system with second component $\mathrm{LiAlCl}_{4}$ is being prepared for publication.

\section{Systems stabilized against crystallization by addition of particulates (work of Pierre Lucas)}

An alternative method of stabilizing a liquid salt against crystallization is to add fine solid granular material to the melt. While the mechanism of this phenomenon is not understood, it seems to be real enough, and the study of its utility for our purposes was the second of our proposed areas of study.

Initial studies showed that the crystallization of a tetrachloroaluminate melt was indeed delayed in the presence of particulate alumina. Attention was then turned to techniques for preparation of ultra fine particulates of inert refractories. The applicability for a sulfate in molten nitrate-nitrite pyrolysis technique developed by Inman et al for $\mathrm{ZrO}_{2}$ to production of other $\mathrm{MO}_{2}$ particulates. We succeeded in producing $\mathrm{ZrO}_{2}$ and $\mathrm{TiO}_{2}$ in crystallites of dimensions so small that they appeared amorphous to $\mathrm{X}$-rays. Transmission electron microscopy however showed the presence of well-defined crystalline layers some $30 \AA$ in diameter. Incorporation of $30 \mathrm{vol} \%$ of these particles in the melt prevents or delays crystallization of otherwise easily crystallizing melts for many hours.

The physical properties of the pastes have not as yet been determined. Further study was sidetracked by the intriguing finding that $\mathrm{LiMn}_{2} \mathrm{O}_{4}$, one of the more promising insertion cathodes materials, could be obtained in nanoscopic particles ry a related process using $\mathrm{MnSO}_{4}$ as the starting material. Much work was done, trying to obtain this material in a form in which it would function as a kinetically superior cathode material for use in reversible lithium batteries. Unfortunately however, despite considerable variation of bath redox potential and thermal conditions, it has not proven possible to obtain it in a state in which it approaches its theoretical 
capacity even though in principle this would seem easier to achieve than with larger particles.

\section{Photovoltaic cells (work of Soley Ozer)}

Studies of photovoltaic cells made up of an n-type Si electrode separated from electronically conducting indium tin oxide coated (transparent) glass counterelectrode separated by an electrolyte solution containing a redox couple have been made using different electrolytes and redox couples. Without giving details of the different cell configurations tried we report here that we have succeeded, using a NaSCN in sulfone-plasticized polyethylene electrolyte and $\mathrm{NaSCN}-\mathrm{Na}_{2} \mathrm{~S} / \mathrm{S}$ redox couple in obtaining open circuit voltages of 0.73 $\mathrm{V}$ and short circuit currents of $20 \mathrm{ma}$, which are unusually good performances. Details will be provided in works to be published. The program is very promising.

\section{Other works}

During this period we have prepared and published two important works of academic synthesis. The first is a paper providing a conceptual overview of the approaches to manipulating the basic salt-in-polymer "solid electrolyte" in all its manifestations. This was prepared as an invited talk for the last international Solid State Ionics conference, held in Singapore. It has now appeared in print.

The second was the report on a workshop on relaxation in amorphous materials, which the P.I. was asked to organize for the DOE. This report covering all aspects of the subject of relaxation has proved to be a massive work. It will be published in $J$. Materials Science.

\section{PUBLICATIONS FROM THE GRANT}

(1) "Probe Ion Diffusivity Measurements in Salt-in-Polymer Electrolytes; Stokes Radii, and the Transport Number Problem," G. McLin and C. A. Angell, J. Phys. Chem. 100, 1181 (1996) Honor issue for Harold Friedman.

(2) "Variations on the Salt-Polymer Electrolyte Theme for Fiexible Solid Electrolytes," C. A. Angell, K. Xu, S-S. Zhang and M. Videa, Text of invited lecture at Takahashi Memorial Symposium, 7th International Conf. Solid State Ionics, Singapore, Dec. 1995, Solid State lonics 86-88, 17-28 (1996)..

(3) "Phase Equilibria, High Conductivity Ambient Temperature Liquids, and Glasses in the Pseudo-Halide Systems 
$\mathrm{AlCl}_{3}-\mathrm{MSCN}(\mathrm{M}=\mathrm{Li}, \mathrm{Na}, \mathrm{K}), "$ Changle Liu and C. A. Angell Solid State Ionics (Proc. 7th Int. Conf. Sol. State Ionics) (in press).

(4) "Relaxation in Glassforming Liquids and Amorphous

Solids: A Report on a Workshop Sponsored by DOE-BES," C. A. Angell, K. L. Ngai, G. B. McKenna, P. F. McMillan, and S. W. Martin (to be submitted).

\section{WORK PROPOSED FOR THE COMING YEAR.}

1. New molten salt systems.

We have not executed the further syntheses proposed in the renewal document and we hope to ac'vance those aims in the coming year. We will need to appoint a new synthetic/physical chemist, as Dr. C. Liu will probably be leaving for another position more suited to his senior status.

The work on mixed chloroaluminates will be pursued both with respect to electrochemical stability and stabilization against crystallization in the hope of obtaining a kinetically stable highconducting ambient temperature electrolyte.

\section{Particulate stabilized electrolytes.}

The work on $\mathrm{ZrO}_{2}$-stabilized $\mathrm{Li}$ salt melts, particularly the high conducting haloaluminates, will be further examined in the expectation that room temperature stabilized systems will be obtainable. Conductivity measurements on the pastes will be of high priority.

\section{Physical measurements}

Physical measurements will receive a boost from the visit to this laboratory of Dr. B. Geil from Germany. He will assist our efforts in NMR relaxation studies of cation conductivity and transport number measurements in various melts and solutions which we have been waiting on for some time.

\section{Photovoltaic cells}

With approval of DOE, student Ozer will be supported to complete the development of the solar cell project. using electrolytes and redox couples generated in the course of our electrolyte and electrode research. 